\title{
Horticultural Characteristics of Transgenic Tobacco Expressing the rolC Gene from Agrobacterium rhizogenes
}

\author{
R. Scorza, T.W. Zimmerman', J.M. Cordts, and K.J. Footen \\ U.S. Department of Agriculture-Agricultural Research Service, Appalachian Fruit Research Station, 45 \\ Wiltshire Road, Kearneysville, WV 25430 \\ M. Ravelonandro \\ Station de Pathologie Vegetale, Institut National Recherche Agronomique, BP 81, 33883 Villenave \\ d'Ornon, France
}

Additional index words. dwarfing, growth regulation, ornamentals

\begin{abstract}
Wisconsin 38' tobacco (Nicotiana tabacum L.) leaf discs were transformed with the disarmed Agrobacterium tumefaciens strain EHA101 carrying the rolC gene from A. rhizogenes (Oono et al., 1987) and NPT II and GUS genes. Shoots that regenerated on kanamycin-containing medium were confirmed as transgenic through GUS assays, polymerase chain reaction (PCR), Southern blot analyses, and transmission of the foreign genes through the sexual cycle. Transgenic plants were as short as half the height of control plants; were earlier flowering by up to 35 days; and had smaller leaves, shorter internodes, smaller seed capsules, fewer seeds, smaller flowers, and reduced pollen viability. The number of seed capsules, leaf number, and specific root length were similar between transgenic and control plants. Transgenic clones varied in the expression of the $\mathrm{rolC}$-induced growth alterations as did the first generation of seedlings from these clones. Such differences suggested the potential for selecting for different levels of expression. Transformation with the rolC gene presents a potentially useful method of genetically modifying horticultural crops, particularly for flowering date, height, and leaf and flower size. Chemical names used: neomycin phosphotransferase (NPTII), $\beta$-glucuronidase (GUS).
\end{abstract}

Altering plant form is a major goal of breeding programs for horticultural crops. Reduced plant size is useful in crops ranging from tree fruit to annual bedding plants. Manipulating flower size is an important component of ornamental crop breeding programs. Most breeding programs depend on hybridization and selection to alter plant and flower form, although irradiation has been used in some cases (Micke et al., 1987).

Another method available to breeders for manipulating horticultural crops genetically is directed gene transfer. While much work has focused on transferring genes for disease and insect resistance, genes that affect plant form are also currently available (Fladung, 1990; Oono et al., 1987; Schmulling et al., 1988; Smigocki and Hammerschlag, 1991; Spena et al., 1987; Tepfer, 1984).

Agrobacterium rhizogenes is the causal agent of hairy root disease of dicotyledonous plants. The disease results from the incorporation of part of the root-inducing (Ri) plasmid into the plant genome and expression of genes in the TL-DNA segment of the transferred DNA. These genes (rolA, $\operatorname{rolB}, \mathrm{rolC}$, and $\mathrm{rolD}$ ) correspond to open reading frames (ORFs) 10, 11, 12, and 15 (Slightom et al., 1986). Plants naturally arising from hairy roots or plants transformed with specific or a combination of rol genes demonstrate an altered morphology. The rolA, rolB, and rolC loci have induced the following characteristic growth alterations: atypical leaf morphology, reduced flower size and pollen production, smaller seed capsules, and increased branching $(\mathrm{rolC})$; alteration

Received for publication 5 Apr. 1993. Accepted for publication 13 Jan. 1994. We gratefully acknowledge A. Callahan for advice and assistance on the molecular verification of plant transformation and G. An, E. Hood, and Y. Oono for providing plasmid pGA482, A. tumefaciens strain EHA 101, and the rolC gene, respectively. The cost of publishing this paper was defrayed in part by the payment of page charges. Under postal regulations, this paper therefore must be hereby marked advertisement solely to indicate this fact.

'Present address: Agriculture Experiment Station, Univ. of the Virgin Islands, RR2, Box 10,000, Kingshill, St. Croix, V.I. 00850. of leaf morphology, increased stigma and flower size, heterostyly, and increased formation of adventitious roots on the stem ( $\mathrm{rolB}$ ); and wrinkled leaves, condensed inflorescences, increased stigma size, and larger flowers (rolA) (Schmulling et al., 1988). The gene products responsible for altered plant morphology have been identified as a $\beta$-glucosidase $(\mathrm{rol} B)$ and a cytokinin- $\beta$-glucosidase (rolC) (Estruch et al., 1991a). The rolC gene product is cell autonomous (Spena et al., 1989), located in the cytosol (Estruch et al., 1991b), and, under its native promoter, expressed exclusively in phloem cells (Sugaya et al., 1989). The effects of rol genes have been studied in tobacco (Schmulling et al., 1988; Spena et al., 1987), potato (Fladung, 1990), tomato (van Altvorst et al., 1992), and other species, yet there is still little detailed quantification of the effects of these genes. Such data is necessary to judge the practical implications of using such genes for altering plant and flower form. The purpose of this study was to examine quantitatively the effects of the rolC gene on plant growth and to assess the horticultural implications of this gene's growth-altering effects. The rolC gene may be particularly useful since plant form seems to be substantially affected without evidence of gross abnormalities such as leaf and flower deformation or excessive aerial rooting that would negatively affect the horticultural value of a crop.

\section{Materials and Methods}

'Wisconsin 38' tobacco plants were obtained as in vitro shoots (Carolina Biological, Burlington, N.C.). These shoots were transferred onto fresh shoot proliferation medium (SPM) consisting of Murashige and Skoog (MS) salts and vitamins (Murashige and Skoog, 1962), $1 \mu_{\mathrm{M}} 1 \mathrm{H}$-indole-3-butyric acid (IBA), and $4.5 \mu \mathrm{M} N$ (furanylmethyl)- $H$-purine-6-amine (kinetin). Leaves were excised and leaf pieces were immersed for $1 \mathrm{~min}$ in an overnight culture of A. tumefaciens strain EHA101 (Hood et al., 1986) carrying an engineered plasmid containing either the NPTII, GUS, and rolC 
genes, or the NPTII and GUS genes only. Following immersion, leaf pieces were blotted briefly and placed on cocultivation medium for 2 days. Cocultivation medium consisted of SPM plus 100 $\mu \mathrm{M}$ acetosyringone. Nontransformed 'Wisconsin 38' controls were not exposed to Agrobacterium. All cultures were maintained at $24 \mathrm{C}$ under 45 to $55 \mu \mathrm{mol} \cdot \mathrm{m}^{-2} \cdot \mathrm{s}^{-1}$ of mixed warm-white fluorescent and Vita-lite full-spectrum fluorescent (Duro Test Corp., Bergen, N.J.) lamps with a 16-h photoperiod. After 2 days, leaf pieces were rinsed in sterile water, blotted, and placed on regeneration medium as described by Oono et al. (1987) with $100 \mathrm{mg} \cdot \mathrm{liter}^{-1}$ kanamycin (kan), $300 \mathrm{mg} \cdot$ liter $^{-1}$ cefotaxime, and $300 \mathrm{mg} \cdot$ liter $^{-1}$ carbenicillin. $^{-}$ Regenerated shoots were excised and placed on rooting medium (half-strength MS salts, MS vitamins, and $20 \mathrm{~g} \cdot$ liter $^{-1}$ sucrose). $^{-}$ Each shoot arising from a leaf piece was designated as a separate clone and subsequently propagated through axillary shoot proliferation to provide multiple plants of each clone for study.

The plasmids used in this study were pGA-GUSGF and pGAGUSGF rolC (Fig. 1). The plasmid pGA-GUSGF was derived from pGA482 (An, 1987) and contains the GUS cassette (Jefferson, 1987). It provides a convenient marker for scoring transformation. The GUS cassette is controlled by the CaMV35S promoter and the 3' untranslated end of the nopaline synthase gene. This GUS cassette was inserted between a HindIII and an EcoRI site by deleting a $2.5-\mathrm{Kb}$ fragment containing the Ori ColE1 and the lambda Cos sites. The pGA-GUSGF plasmid was used in this study as a control for the effects of the rolC gene vs. the effects of the plasmid without rolC. The plasmid pGA-GUSGF rolC was developed by excising the rolC insert from the plasmid Bin 19-ORF12 supplied by Y. Oono (Oono et al., 1987) (Fig. 1). The rolC insert was ligated into pGA-GUSGF to produce pGA-GUSGF rolC.

After rooting, plantlets were placed in sterile potting mix in Phytatray II vessels (Sigma Chemical Co., St. Louis). These in vitro-grown plants were acclimated to ambient conditions by incrementally venting the vessels for 1 week. Plants were $\approx 8 \mathrm{~cm}$ high when transferred to the greenhouse. They were placed under a regular schedule of irrigation, fertilization, and insect control. The first set of plants, which included transgenic clones A, B, E, and $\mathrm{G}$ plus open-pollinated 'Wisconsin 38' controls, was placed in the greenhouse in December. High-pressure sodium lighting provided $\approx 350 \mu \mathrm{M} \cdot \mathrm{m}^{-2} \cdot \mathrm{s}^{-1} 0.5 \mathrm{~m}$ from the source and supplemented the natural daylength from December to February providing a 16-h photoperiod. At about 1 Mar., lights were no longer used and plants grew under the natural daylength, which ranged from $\approx 9$ to $14 \mathrm{~h}$ for the rest of the test. The experiment was repeated using two transgenic clones, $\mathrm{F}$ and $\mathrm{G}$, with open-pollinated untransformed 'Wisconsin 38' controls and controls (clone 73) transgenic for the engineered plasmid without the rolC gene (pGA-GUSGF). This set of plants was multiplied in vitro and placed in the greenhouse in June. This provided a natural daylength of $\approx 13 \mathrm{~h}$ at the beginning of the study and $9 \mathrm{~h}$ by the end of the study.

Seed production. Plants of transgenic rolC clones B, E, and $\mathrm{F}$ and two controls (clone 73, which contained plasmid pGA-GUSGF, and untransformed 'Wisconsin 38') were used for self-pollination and seed production. Flower stalks of these plants were bagged until it was apparent that flowers selected for seed production were fertilized. Mature seeds were collected and stored at 4C. Seeds were surface-disinfested for $10 \mathrm{~min}$ in $15 \%$ commercial bleach $(0.8 \%$ sodium hypochlorite) with $0.01 \%$ Tween- 20 , rinsed in sterile deionized water, and planted on agar-solidified (noble agar; U.S. Biochemical Corp., Cleveland) medium containing halfstrength MS salts plus $100 \mathrm{mg} \cdot$ liter $^{-1} \mathrm{kan}$. Seeds of nontransgenic controls ('Wisconsin 38' not exposed to Agrobacterium) were not exposed to kan. Preliminary trials indicated that control seedlings were killed by $100 \mathrm{mg} \cdot$ liter $^{-1} \mathrm{kan}_{\text {(data not presented). Transgenic }}$ seedlings that survived kan selection and nontransgenic controls were transplanted to the greenhouse as previously described.

The following measurements were taken on plants depending on the particular trial. a) Plant height at flowering - measured from the soil line to the base of the flower stalk. b) Final plant heightincluding the flowering stalk, measured at the completion of flower stalk elongation. c) Plant dry weight-plants were harvested at ground level following the maturity of all seed capsules. Dry weight of the flowering stalk was not included. d) Leaf number - the number of leaves or nodes at the time of flowering not including leaves or nodes on flowering stalks. e) Leaf areameasured on a sample of three fully expanded leaves from the middle area of the plant, sampled at flowering initiation. Area was measured using a portable area meter (LI 3050A; LI-COR, Lincoln, Neb.). f) Photosynthesis rate-measured on an overcast day using a portable photosynthesis system (LI 6250; LI-COR). Three areas of each of two leaves were measured per plant. g) Stomatal conductance - measured at the same time as rate of photosynthesis using the portable photosynthesis system. h) Specific root lengthmeasured by taking a random sampling of roots. These samples were then dried at 70C and this dry weight was used to calculate the root dry weight per unit length (Eissenstat, 1992). This measurement was taken after all other measurements had been taken. i) Flowering date - the date of anthesis of the first flower. In all cases, flowering initiation was followed by a sequential maturation of all flowers on a plant. j) Length of flowering period-days from the opening of the first to the last flower. k) Corolla length-length of the flower from the base to the apex, measured on a random sample of 20 mature flowers per plant taken at the mid-flowering period. 1) Corolla diameter-measured across the flower opening on a random sample of 20 mature flowers per plant taken at the mid-flowering period. m) Pollen viability-pollen was germi-

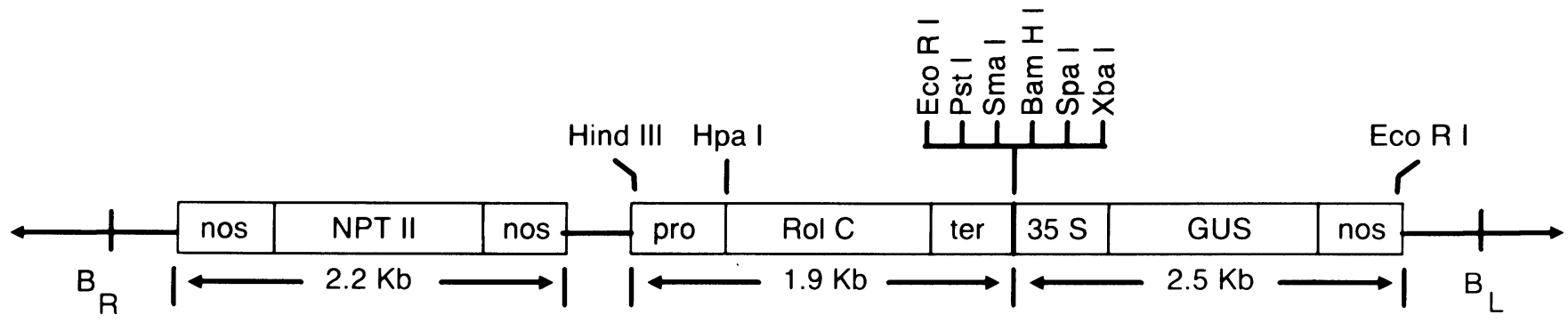

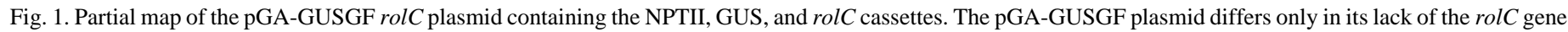
and associated promoter and terminator. 
nated on the medium described by Werner and Chang (1981). Germination was evaluated at 24 and $48 \mathrm{~h}$ (48-h data is presented in this report). Pollen was considered viable only if the pollen-tube length was at least twice the diameter of the swollen pollen grain. n) Capsule number - the total number of seed capsules produced per plant. o) Seed capsule length and width-in the first experiment, all seed capsules were measured. In subsequent experiments, a random sample of 20 capsules per plant was measured. p) Seed weight per capsule - seeds of all capsules were weighed in the first experiment. In subsequent experiments, a random sample of 10 capsules per plant was measured.

Analysis of variance was used to determine differences between treatments. In the first set of experiments (Table 1), 10 plants per clone were used. In the second trial (Table 2), five plants per clone were evaluated. In the seedling test (Table 3), 10 seedling plants per clone were measured.

Confirmation of transformation. After being regenerated on $100 \mathrm{mg} \cdot$ liter $^{-1} \mathrm{kan}$, shoots were transferred to rooting medium containing the same kan level. At the time of transfer to rooting medium, leaf pieces were evaluated for GUS expression using the fluorescent and histochemical assays (Jefferson, 1987). Each clone was evaluated further for the presence of foreign genes through polymerase chain reaction (PCR) (Hamill et al., 1991) and Southern analysis (Southern, 1975). Genomic DNA was extracted from leaves of transgenic and untransformed tobacco following a CTAB protocol (Doyle and Doyle, 1990). PCR reactions were run using a gene amplification kit and thermal cycler (Perkin Elmer Cetu, Norwalk, Conn.). The oligonucleotide primers for a 514-bp internal fragment of the rolC gene were $5^{\prime}$ primer, 5'CGACCTGTGTTCTCTCTTTTTCAAGC and 3' primer, and 5' GCACTCGCCATGCCTCACCAACTCACC. The primers for the GUS and NPTII genes were supplied by J.L. Slightom and were those described by Fitch et al. (1992). The thermal sequence for 30 cycles was $1 \mathrm{~min}$ at 94C, $2 \mathrm{~min}$ at $60 \mathrm{C}$, and $3 \mathrm{~min}$ at $72 \mathrm{C}$. For Southern analysis, $20 \mu \mathrm{g}$ of genomic DNA was digested with EcoRI and HindIII to verify the presence of the 1.9-Kb rolC insert (Fig. 1). A HindIII digest was used to determine the integration of the rolC insert into the plant genome and the number of insertion events. The digested DNA was run in a $0.7 \%$ agarose gel and transferred onto a nylon membrane following the Oncor (Gaithersburg, Md.) protocol. The 514 bp internal rolC fragment used as a probe was generated through PCR using the previously described primers and thermal cycler conditions. After PCR amplification, the reaction was ethanol-precipitated, eluted through an elutipD column according to the manufacturer's conditions (Schliecher and Schuell, Keene, N.H.), and ethanol-precipitated another two times. The fragment was labeled using a random primer kit (BRL, Gaithersburg) and 32[P]CTP (NEN, Boston). Membranes were probed $16 \mathrm{~h}$ with the random primed rolC fragment and washed three times with $0.1 \mathrm{x}$ SSC $\left(0.88 \mathrm{~g} \cdot\right.$ liter $^{-1}$ $\mathrm{NaCl}, 0.44 \mathrm{~g} \cdot$ liter $^{-1}$ sodium citrate) at room temperature and twice with $0.1 \mathrm{x}$ SSC at $65 \mathrm{C}$. The blots were exposed to X-ray film with two intensifier screens at $-80 \mathrm{C}$.

\section{Results}

Confirmation of transformation. Putative transformants were selected based on regeneration under kan selection, shoot proliferation, and rooting in the presence of $100 \mathrm{mg} \cdot \mathrm{liter}^{-1} \mathrm{kan}$. Control 'Wisconsin 38' shoots died at this concentration of kan. Positive GUS assays also indicated transformation except for clones A and $\mathrm{G}$, which grew on kan but were negative for GUS expression. PCR analyses confirmed the integration of the GUS, NPT II, and rolC genes in all clones except $A$ and $G$ in which the GUS gene was not

Table 1. Horticultural characteristics of transgenic tobacco expressing the rolC gene (December planting).

\begin{tabular}{lcccc}
\hline \hline $\begin{array}{l}\text { Tobacco } \\
\text { plant }\end{array}$ & $\begin{array}{c}\text { Ht at } \\
\text { flowering } \\
(\mathrm{cm})\end{array}$ & $\begin{array}{c}\text { No. of } \\
\text { leaves } \\
(\text { nodes })\end{array}$ & $\begin{array}{c}\text { Leaf area } \\
\left(\mathrm{cm}^{2}\right)\end{array}$ & $\begin{array}{c}\text { Photosynthesis rate } \\
\left(\mu \mathrm{M} \mathrm{CO}_{2} / \mathrm{m}^{2} \text { per sec }\right)\end{array}$ \\
\hline Control & $161.8 \mathrm{a}^{\mathrm{z}}$ & $20 \mathrm{a}$ & $229.9 \mathrm{a}$ & $11.0 \mathrm{a}$ \\
rolC A & $102.6 \mathrm{~b}$ & $20 \mathrm{a}$ & $162.2 \mathrm{~b}$ & $11.5 \mathrm{a}$ \\
rolC B & $142.3 \mathrm{a}$ & $24 \mathrm{a}$ & $144.2 \mathrm{~b}$ & $10.4 \mathrm{a}$ \\
rolC $\mathrm{E}$ & $86.3 \mathrm{~b}$ & $21 \mathrm{a}$ & $142.2 \mathrm{~b}$ & $\mathrm{ND}^{\mathrm{y}}$ \\
rolC G & $91.0 \mathrm{~b}$ & $21 \mathrm{a}$ & $166.0 \mathrm{~b}$ & $\mathrm{ND}$
\end{tabular}

\begin{tabular}{|c|c|c|c|c|}
\hline & $\begin{array}{c}\text { Stomatal } \\
\text { conductance } \\
\left(\mathrm{cm} \cdot \mathrm{s}^{-1}\right)\end{array}$ & $\begin{array}{l}\text { Specific root } \\
\text { length }\left(\mathrm{g} \cdot \mathrm{m}^{-1}\right)\end{array}$ & $\begin{array}{c}\text { Flowering } \\
\text { date }\end{array}$ & $\begin{array}{c}\text { Total no. of } \\
\text { seed capsules }\end{array}$ \\
\hline Control & $0.96 \mathrm{~b}$ & $173.8 \mathrm{a}$ & 7 Apr. a & $48 \mathrm{ab}$ \\
\hline $\operatorname{rolC~A}$ & $1.22 \mathrm{a}$ & $152.3 \mathrm{a}$ & 11 Mar. b & $59 \mathrm{ab}$ \\
\hline rolc B & $1.17 \mathrm{a}$ & $173.7 \mathrm{a}$ & 16 Mar. b & $71 \mathrm{ab}$ \\
\hline rolc $\mathrm{E}$ & ND & $164.0 \mathrm{a}$ & 2 Mar. b & $76 \mathrm{a}$ \\
\hline rolc $\mathrm{G}$ & ND & $153.5 \mathrm{a}$ & 28 Feb. b & $45 \mathrm{~b}$ \\
\hline
\end{tabular}

\begin{tabular}{lccccc} 
& $\begin{array}{c}\text { Capsule } \\
\text { length } \\
(\mathrm{mm})\end{array}$ & $\begin{array}{c}\text { Capsule } \\
\text { width } \\
(\mathrm{mm})\end{array}$ & $\begin{array}{c}\text { Seed wt/ } \\
\text { capsule } \\
(\mathrm{mg})\end{array}$ & $\begin{array}{c}\text { Corolla } \\
\text { length } \\
(\mathrm{mm})\end{array}$ & $\begin{array}{c}\text { Pistil } \\
\text { length } \\
(\mathrm{mm})\end{array}$ \\
\hline Control & $21.1 \mathrm{a}$ & $10.9 \mathrm{a}$ & $209.6 \mathrm{a}$ & $49.3 \mathrm{a}$ & $46.8 \mathrm{a}$ \\
rolC A & $19.5 \mathrm{~b}$ & $10.2 \mathrm{~b}$ & $208.1 \mathrm{a}$ & $48.3 \mathrm{a}$ & $44.5 \mathrm{ab}$ \\
rolC B & $16.1 \mathrm{~d}$ & $8.6 \mathrm{~d}$ & $103.2 \mathrm{c}$ & $45.8 \mathrm{a}$ & $46.0 \mathrm{a}$ \\
rolC E & $15.9 \mathrm{~d}$ & $9.2 \mathrm{c}$ & $104.6 \mathrm{c}$ & $40.4 \mathrm{~b}$ & $38.3 \mathrm{c}$ \\
rolC G & $16.9 \mathrm{c}$ & $8.7 \mathrm{~cd}$ & $137.4 \mathrm{~b}$ & $45.5 \mathrm{a}$ & $43.5 \mathrm{~b}$ \\
\hline
\end{tabular}

${ }^{\mathrm{z}}$ Mean separation in columns by Duncan's multiple range test, $P=0.05$.

${ }^{\mathrm{y}} \mathrm{ND}=$ no data. 
Table 2. Horticultural characteristics of transgenic tobacco expressing the rolC gene (June planting).

\begin{tabular}{|c|c|c|c|c|c|}
\hline $\begin{array}{l}\text { Tobacco } \\
\text { plant }\end{array}$ & $\begin{array}{c}\text { Ht at } \\
\text { flowering } \\
(\mathrm{cm})\end{array}$ & $\begin{array}{l}\text { Final } \\
\text { ht } \\
(\mathrm{cm})\end{array}$ & $\begin{array}{l}\text { Total plant } \\
\text { dry wt } \\
\text { (g) }\end{array}$ & $\begin{array}{l}\text { Leaf } \\
\text { area } \\
\left(\mathrm{cm}^{2}\right)\end{array}$ & $\begin{array}{c}\text { Specific root } \\
\text { length } \\
\left(\mathrm{g} \cdot \mathrm{m}^{-1}\right)\end{array}$ \\
\hline Control & $127.6 \mathrm{a}^{\mathrm{z}}$ & $146.0 \mathrm{a}$ & $84.4 \mathrm{a}$ & $352.3 \mathrm{a}$ & $62.7 \mathrm{a}$ \\
\hline $73 \mathrm{~A}$ & $108.8 \mathrm{a}$ & $132.4 \mathrm{a}$ & $72.2 \mathrm{a}$ & $281.9 \mathrm{~b}$ & $76.7 \mathrm{a}$ \\
\hline $73 \mathrm{~B}$ & $108.7 \mathrm{a}$ & $130.3 \mathrm{a}$ & $70.5 \mathrm{a}$ & $293.2 \mathrm{~b}$ & $78.6 \mathrm{a}$ \\
\hline $\operatorname{rolC} \mathrm{F}$ & $69.6 \mathrm{~b}$ & $92.0 \mathrm{~b}$ & $31.6 \mathrm{~b}$ & $186.0 \mathrm{c}$ & $84.7 \mathrm{a}$ \\
\hline \multirow[t]{2}{*}{ rolc $\mathrm{G}$} & $67.8 \mathrm{~b}$ & $82.8 \mathrm{~b}$ & $32.0 \mathrm{~b}$ & $177.2 \mathrm{c}$ & $96.3 \mathrm{a}$ \\
\hline & $\begin{array}{c}\text { Flowering } \\
\text { date }\end{array}$ & $\begin{array}{c}\text { Flowering } \\
\text { period } \\
\text { (days) }\end{array}$ & $\begin{array}{l}\text { Corolla } \\
\text { length } \\
(\mathrm{mm})\end{array}$ & $\begin{array}{l}\text { Corolla } \\
\text { diam } \\
(\mathrm{mm})\end{array}$ & $\begin{array}{c}\text { Pollen } \\
\text { germination } \\
(\%)\end{array}$ \\
\hline Control & 27 Aug. a & $35 \mathrm{a}$ & $48.8 \mathrm{a}$ & $18.8 \mathrm{~b}$ & $67 \mathrm{a}$ \\
\hline $73 \mathrm{~A}$ & 13 Aug. b & $24 \mathrm{bc}$ & $49.0 \mathrm{a}$ & $20.6 \mathrm{a}$ & $61 \mathrm{a}$ \\
\hline $73 B$ & 10 Aug. b & $19 \mathrm{c}$ & $49.3 \mathrm{a}$ & $19.2 \mathrm{~b}$ & $\mathrm{ND}^{\mathrm{y}}$ \\
\hline $\operatorname{rolc} \mathrm{F}$ & 21 July c & $29 \mathrm{abc}$ & $40.0 \mathrm{~b}$ & $16.4 \mathrm{c}$ & $49 a b$ \\
\hline \multirow[t]{2}{*}{$\operatorname{rolC~G}$} & 23 July c & $34 \mathrm{ab}$ & $40.1 \mathrm{~b}$ & $16.7 \mathrm{c}$ & $22 \mathrm{~b}$ \\
\hline & & $\begin{array}{c}\text { Total no. } \\
\text { of seed } \\
\text { capsules }\end{array}$ & $\begin{array}{l}\text { Capsule } \\
\text { length } \\
(\mathrm{mm})\end{array}$ & $\begin{array}{c}\text { Capsule } \\
\text { width } \\
(\mathrm{mm})\end{array}$ & $\begin{array}{l}\text { Seed wt/ } \\
\text { capsule } \\
(\mathrm{mg})\end{array}$ \\
\hline Control & & $85.2 \mathrm{a}$ & $20.0 \mathrm{~b}$ & $10.8 \mathrm{c}$ & $155.8 \mathrm{~b}$ \\
\hline $73 \mathrm{~A}$ & & $51.4 \mathrm{~b}$ & $22.1 \mathrm{a}$ & $11.1 \mathrm{~b}$ & $171.1 \mathrm{~b}$ \\
\hline $73 \mathrm{~B}$ & & $73.3 \mathrm{ab}$ & $22.2 \mathrm{a}$ & $11.5 \mathrm{a}$ & $199.5 \mathrm{a}$ \\
\hline $\operatorname{rolc} \mathrm{F}$ & & $66.8 \mathrm{ab}$ & $17.1 \mathrm{c}$ & $10.5 \mathrm{c}$ & $174.0 \mathrm{~b}$ \\
\hline rolc $\mathrm{G}$ & & $51.4 \mathrm{~b}$ & $15.2 \mathrm{~d}$ & $8.2 \mathrm{~d}$ & $86.1 \mathrm{c}$ \\
\hline
\end{tabular}

${ }_{\mathrm{z}}$ Mean separation in columns by Duncan's multiple range test, $P=0.05$.

${ }^{\mathrm{N} D}=$ no data

Table 3. Horticultural characteristics of progeny from self-pollination of tobacco plants expressing the rolC gene.

\begin{tabular}{|c|c|c|c|c|c|}
\hline $\begin{array}{l}\text { Tobacco } \\
\text { plant }\end{array}$ & $\begin{array}{c}\text { Ht at } \\
\text { flowering } \\
(\mathrm{cm})\end{array}$ & $\begin{array}{c}\text { Final } \\
\mathrm{ht} \\
(\mathrm{cm})\end{array}$ & $\begin{array}{l}\text { Leaf } \\
\text { area } \\
\left(\mathrm{cm}^{2}\right)\end{array}$ & $\begin{array}{c}\text { Flowering } \\
\text { date }\end{array}$ & $\begin{array}{c}\text { Seed wt/ } \\
\text { capsule } \\
(\mathrm{mg})\end{array}$ \\
\hline Control & $130.8 \mathrm{a}^{\mathrm{z}}$ & $138.9 \mathrm{a}$ & $725.6 \mathrm{a}$ & 19 Apr. a & $131.4 \mathrm{a}$ \\
\hline 73 & $129.4 \mathrm{a}$ & $131.4 \mathrm{a}$ & $655.6 \mathrm{~b}$ & 18 Apr. a & $143.6 \mathrm{a}$ \\
\hline $\operatorname{rolc} \mathrm{B}$ & $102.3 \mathrm{~b}$ & $115.3 \mathrm{ab}$ & $381.0 \mathrm{c}$ & 12 Apr. ab & $32.9 \mathrm{c}$ \\
\hline $\operatorname{rolc} \mathrm{E}$ & $72.3 \mathrm{c}$ & $98.1 \mathrm{~b}$ & $375.3 \mathrm{c}$ & 13 Apr. ab & $48.8 \mathrm{bc}$ \\
\hline $\operatorname{rolc} \mathrm{F}$ & $68.8 \mathrm{c}$ & $101.0 \mathrm{~b}$ & $372.0 \mathrm{c}$ & 9 Apr. b & $72.5 \mathrm{~b}$ \\
\hline
\end{tabular}

${ }^{\mathrm{z}}$ Mean separation in columns by Duncan's multiple range test, $P=0.05$.

detected. Control plants were negative (Fig. 2). Southern analysis with the combined EcoRI and HindIII digestion demonstrated that all of the transgenic clones contained the $1.9-\mathrm{Kb}$ rolC fragment. (Fig. 3). Using HindIII alone, the Southern analysis revealed a single fragment in transgenic clones $\mathrm{A}$ and $\mathrm{G}$ at 4.0 and $3.9 \mathrm{~Kb}$, respectively. Clone B produced a $14.0-\mathrm{Kb}$ fragment. Clone $\mathrm{E}$ produced three bands: 7.4, 5.2, and $2.0 \mathrm{~Kb}$. Clone $\mathrm{F}$ produced a 11.0- and 4.8-Kb band (Fig. 3). The presence of multiple bands in clones $\mathrm{E}$ and $\mathrm{F}$ indicates multiple insertions of the rolC gene. The 2.0- $\mathrm{Kb}$ fragment in clone $\mathrm{E}$, which closely approximates the 1.9$\mathrm{Kb}$ rolC insert, suggests multiple tandem insertions of the rolC gene along with a deletion of the GUS and NPTII genes at the tandem insertion site. Tandem and other complex insertion patterns have been previously reported (Rotino et al., 1992). An explanation for the high expression of rolC traits in clone $\mathrm{E}$ (Table 1) may be the multiple insertions of the rolC gene.

Transgenic clones $A, B, E$, and $G$, December planting. Plants expressing the rolC gene were shorter, produced smaller leaves, and were earlier flowering than the 'Wisconsin 38' control (Table 1, Figs. 4 and 5). Seed capsules were smaller, and most transgenic clones when self-pollinated produced fewer seeds than the controls. The number of seed capsules, number of leaves (nodes), photosynthetic rate, and specific root length did not differ between transgenic and control plants. Stomatal conductance was generally higher in transgenic clones. Clones $\mathrm{E}$ and $\mathrm{G}$ demonstrated the most extreme examples of rolC traits in this trial, with up to a $53 \%$ reduction in plant height, twice the number of nodes per unit height (short internodes), a 62\% reduction in leaf area, and a 50\% reduction in seed weight per capsule.

Transgenic clones $F$ and $G$, June planting. Control plants in this trial included 'Wisconsin 38' and two clones, 73A and 73B, which contained the pGA-GUSGF plasmid insert without the rolC gene. These plasmid controls generally did not differ from untransformed 'Wisconsin 38', although for a few measured traits they were midway between control and transgenic plants (Table 2). As in the first trial, rolC transgenic plants were shorter with smaller leaves, produced smaller seed capsules, and were earlier flowering than control plants. The length of the flowering period did not differ between transgenics and controls. Total above-ground dry weight of rolC transgenic plants was less than half that of control plants. 
In this trial, clone $\mathrm{G}$ produced fewer seeds than controls on selfpollination, but clone F did not. Pollen germination of clone $\mathrm{G}$ was less than half that of clone $\mathrm{F}$ and about one-third that of controls,

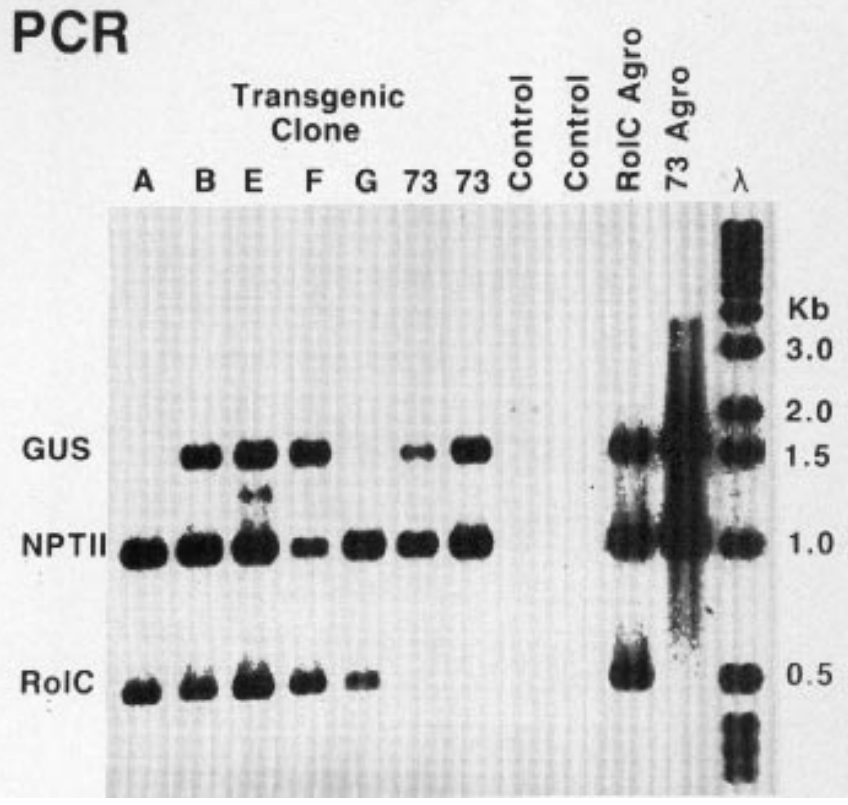

Fig. 2. PCR analysis of rol $C$ transgenic clones A, B, E, F, and $\mathrm{G}$ and two regenerated plants following transformation with a plasmid containing the NPTII and GUS but not the rolC gene (plasmid pGA-GUSGF). Negative controls are untransformed tobacco controls. Positive controls are Agrobacterium tumefaciens containing the plasmids. Note the absence of the expected GUS gene in clones A and G. which may account for the low seed number obtained. Flowers of rolC transgenic plants were smaller than those of controls, $\approx 15 \%$ shorter in length and in the diameter of the corolla.

Analysis of seedlings of transgenic clones. Samples of 100 seeds from each of the self-pollinated clones B, E, and F were germinated at least twice. Seedling survival rates fit a 3 kan resistant : 1 kan sensitive ratio $\left(\chi^{2}, P=0.01\right)$. Seedlings from untransformed controls all died after 3 weeks on $100 \mathrm{mg} \cdot \mathrm{liter}^{-1} \mathrm{kan}$. The appearance of vigorous and weak transgenic seedlings on kan led to a germination test of clones $\mathrm{B}$ and $\mathrm{E}$ and a nontransgenic control on $0,25,50,100$, and $150 \mathrm{mg} \cdot \mathrm{liter}^{-1} \mathrm{kan}$. This test revealed that, at the 100 to $150 \mathrm{mg} \cdot$ liter $^{-1} \mathrm{kan}$ concentrations, ratios of $3 \mathrm{kan}$ resistant : 1 kan sensitive were consistent $\left(\chi^{2}, P=0.01\right)$, but, at the 25 to $50 \mathrm{mg} \cdot \mathrm{liter}^{-1} \mathrm{kan}$ levels, a higher percentage of seedlings from clone B died than from clone E $(20 \%$ vs. $7 \%)$. This indicated a higher expression of the NPTII gene in clone E seedlings and possibly a higher gene copy number. The higher gene copy number, which would result from a tandem insertion event as suggested by Southern analysis, is consistent with the observed ratio of 3 kan resistant : 1 kan sensitive seedlings.

A subsample of 10 kan resistant seedlings from transgenic clones B, E, and F was analyzed for expression of the GUS gene. All were positive, while controls were negative. These seedlings were transferred into the greenhouse in February with supplemental lighting as described earlier. Growth parameters that were found to best distinguish rolC expression were measured on these plants and they were typical for rolC expression: shorter stature, with smaller leaves, fewer seeds, and earlier blooming (Table 3). We noted that, overall, seedlings of the different clones varied in

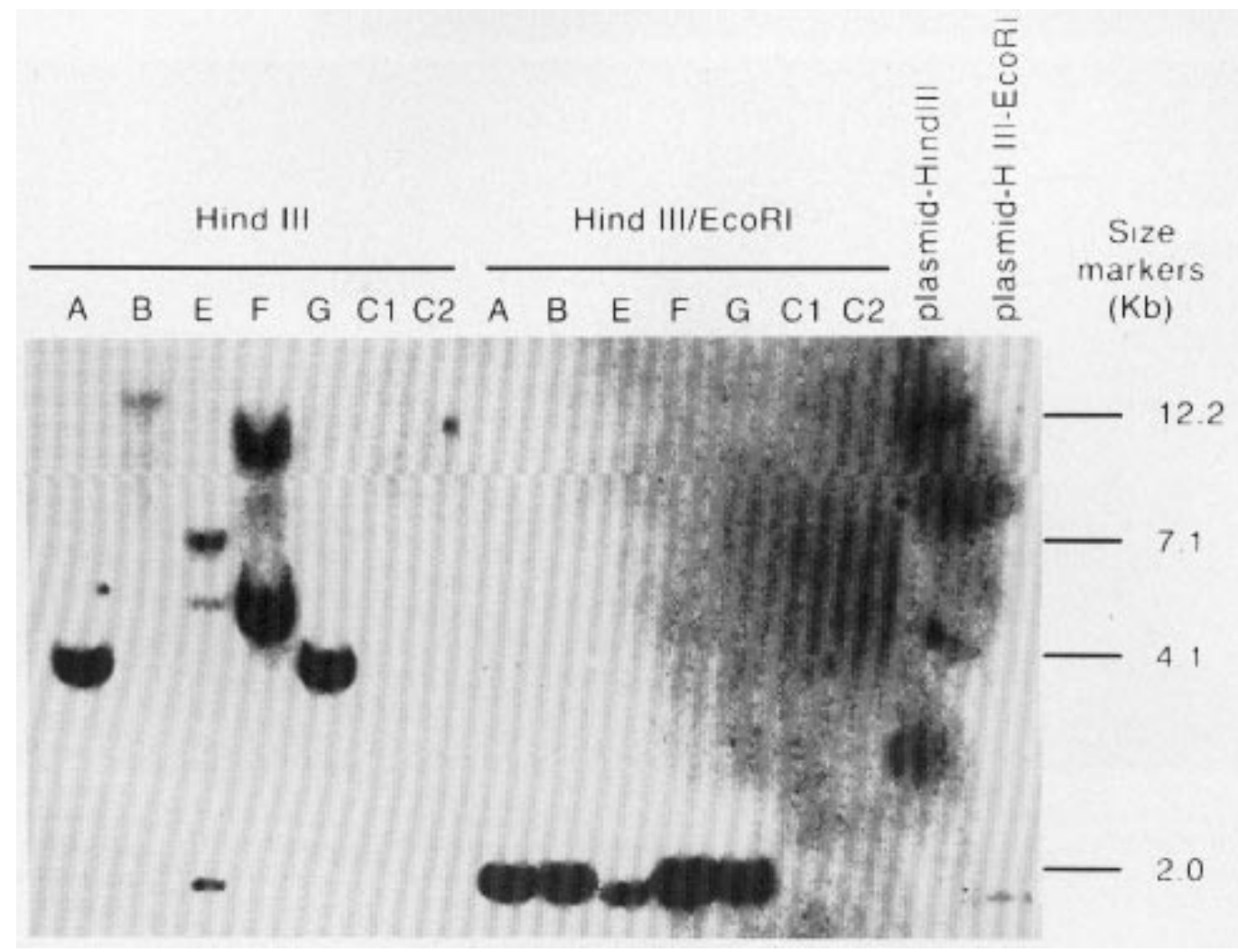

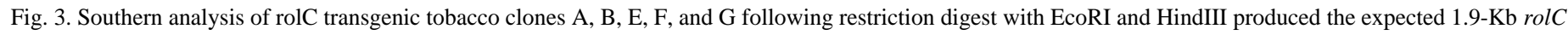

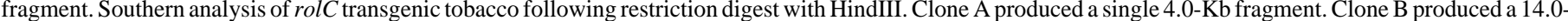

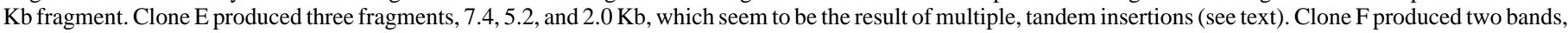

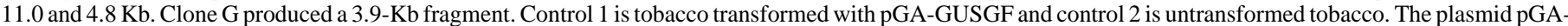
GUSGF rolC digested with HindIII and HindIII/EcoRI is also shown. 

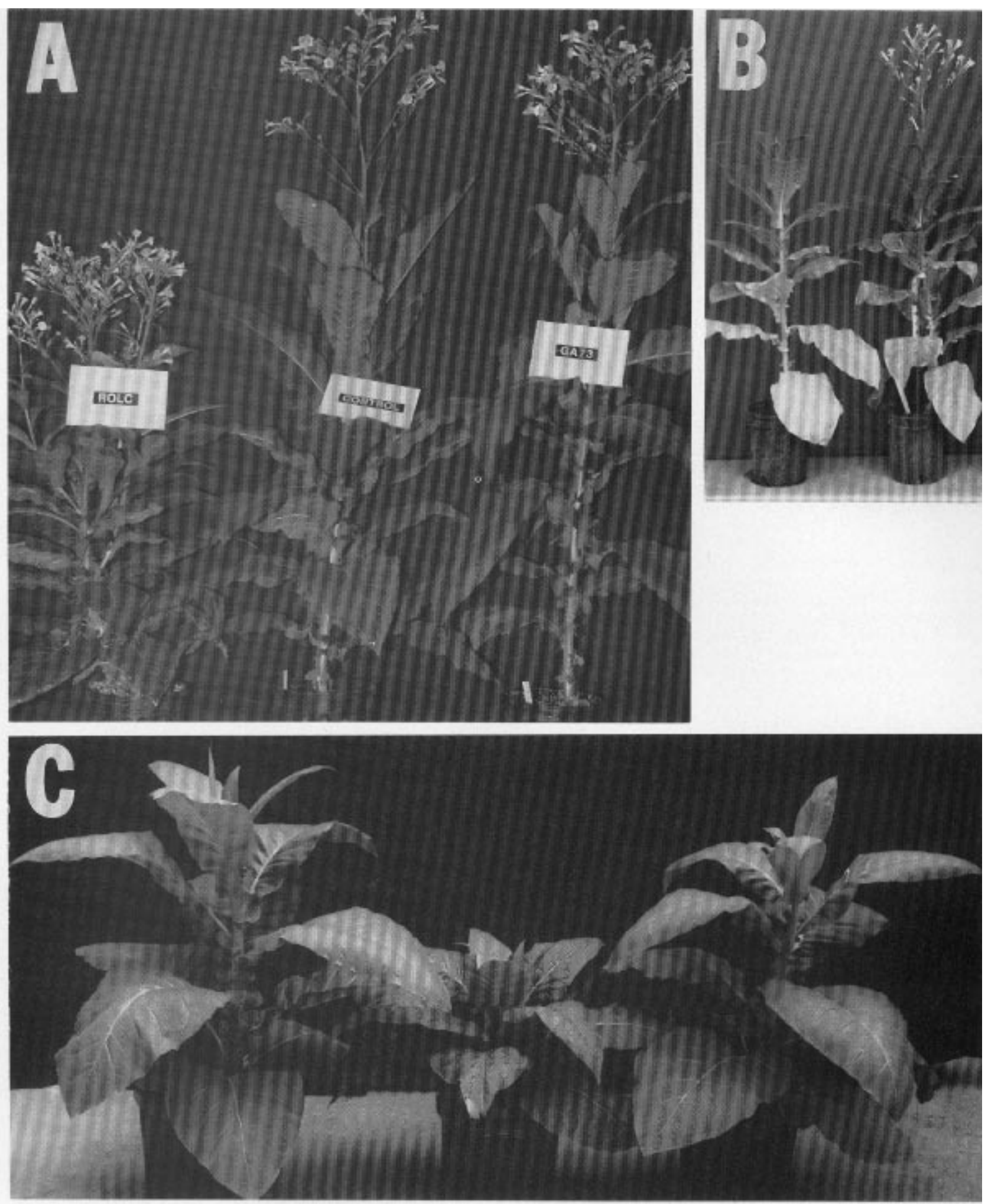

Fig. 4. (A) RolC transgenic tobacco clone F (left), untransformed 'Wisconsin 38' (middle), and transgenic clone 73 without the rolC gene (transformed with pGAGUSGF) (right). (B) Plants of transgenic clone F (right) flowered $\approx 35$ days before the untransformed controls (left). (C) Seedling of transgenic clone 73 without the rolC gene (plasmid pGA-GUSGF) (left), rolC transgenic clone (plasmid pGA-GUSGF rolC) (middle), and untransformed 'Wisconsin 38' (right).

the degree of expression of rolC traits. Seedlings of clones E and F were more extreme in their expression of $r o l C$ traits than clone B seedlings. This also may be evidence of multiple, tandem insertions, which would corroborate the results of kan resistance and Southern analysis.

Besides differences between expression of rolC traits between transgenic clones, our work with seedlings of these clones indicated that individual seedlings within a clone differed in their expression of rolC traits. To study these differences further, an additional 50 clone E seedlings, which survived kan selection and were GUS positive, were planted in the greenhouse in April without supplemental lighting. Along with these, 10 untransformed 


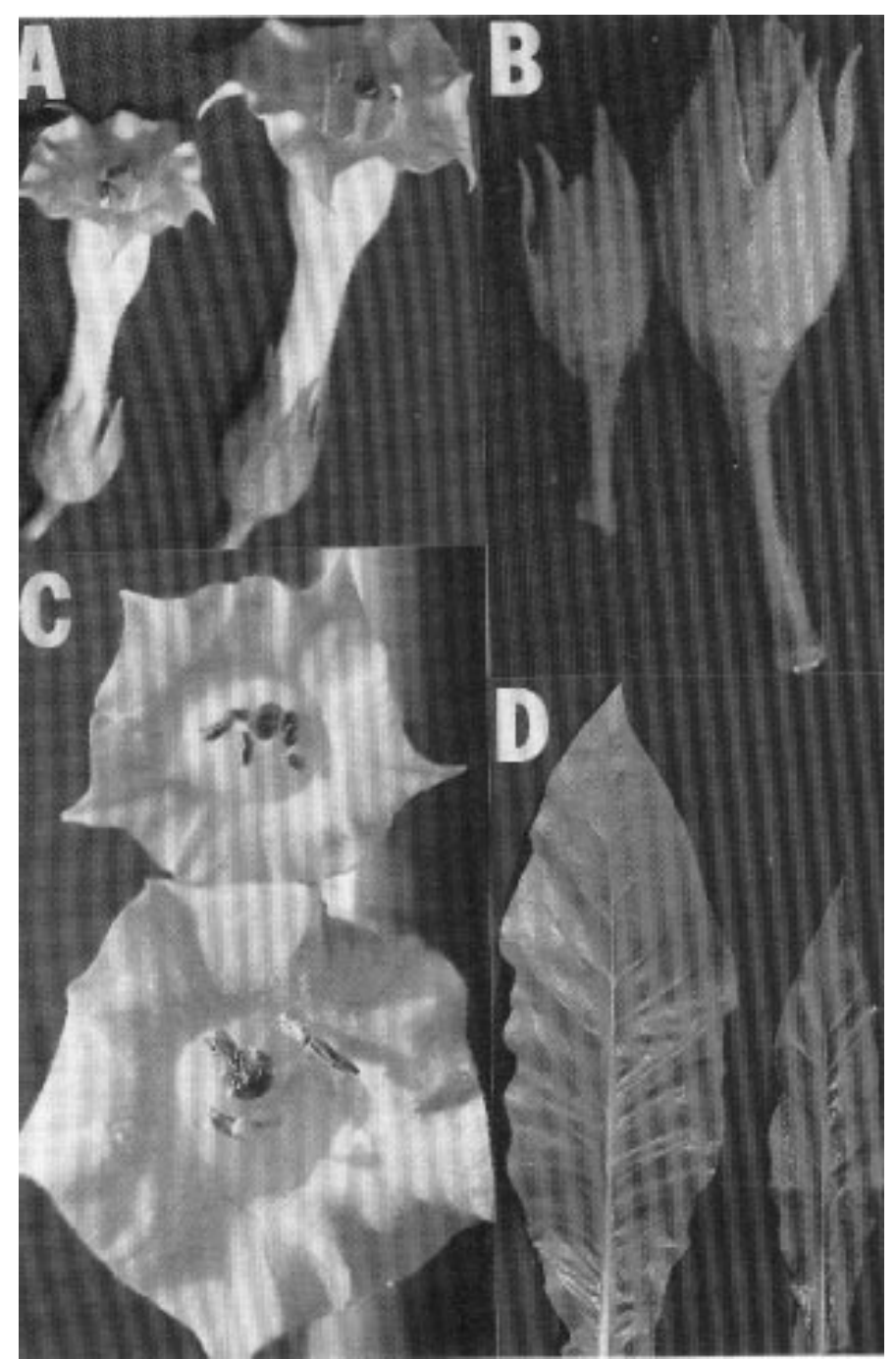

Fig. 5. (A) Flower of rolC transgenic tobacco (left) and untransformed control (right). (B) Seed capsule of rolC transgenic plant (left) and untransformed control (right). (C) Flower of rolC transgenic tobacco (top) and untransformed control (bottom). (D) Leaf of untransformed control tobacco (left) and rolC transgenic (right).

'Wisconsin 38' untransformed control seedlings were planted having been germinated at the same time, in the absence of kan. Height, leaf area, flowering date, and seed production were measured as previously described. In addition, the number of lateral shoots produced from the soil line to the base of the flowering stalk was recorded at the time of flowering and the total number of flowers produced on the main flowering stalk was counted. Since these seedlings tested positive for kan resistance and since they were GUS positive, we assumed that they carried the rolC gene. Further, if we assume that three copies of the introduced genes were inserted in tandem in clone E as suggested by Southern analysis, 3:1 segregation ratios, and extreme expression of the rolC phenotype, then, following the death on kan-containing medium of seedlings homozygous for the absence of the introduced genes, we would expect a ratio of 2 heterozygotes : 1 homozygote for the introduced genes. Cumulative frequency of measurements for the 50 seedlings was calculated using SAS's PROC CHART (SAS, 1979). While these seedlings expressed typical rolC traits such as reduced height and smaller leaves when compared with controls, a ratio of 2 expression : 1 extreme expression of rolC traits was not observed (Fig. 6). Using the mean trait expression for rolC plants, in every case there were fewer plants that showed extreme expres-
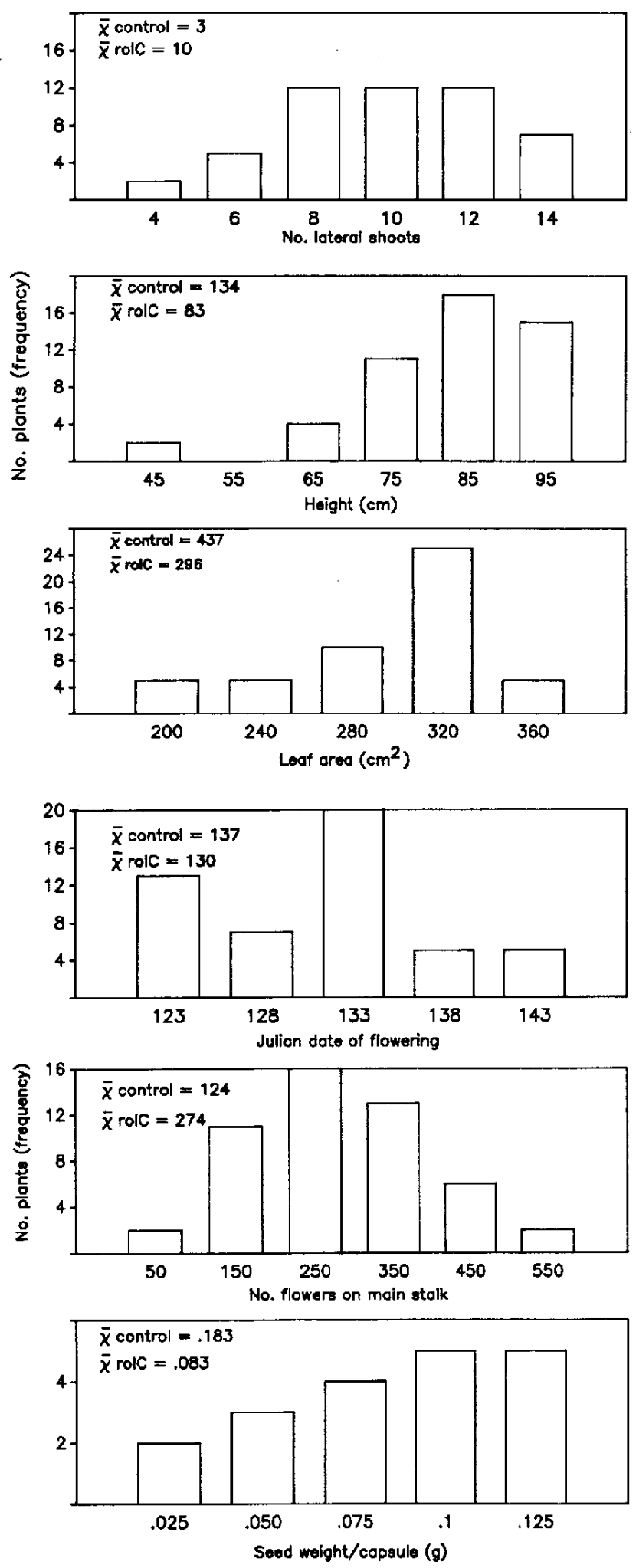

Fig. 6. Cumulative frequency measurements of 50 seedlings of $\mathrm{rolC}$ transgenic tobacco clone E. Seed weight per capsule based on the mean of 10 capsules for each of 20 plants. Means for untransformed controls and rolC transgenic plants are also indicated.

sion than those that showed expression of traits above the mean (Fig. 6). Thus, although there was not a 2:1 ratio, there were fewer extreme expressers, as would be expected. The fact that plant-growth regulators interact with each other and the environment in complex ways makes it not surprising that a clear 2:1 ratio was not observed. 


\section{Discussion}

The rolC gene has proved to be useful for studying A. rhizogenes control of hairy root development (Tepfer, 1984). Studies of the combined effects of the products of $\mathrm{rolA}$, $\mathrm{rolB}$, and $\mathrm{rolC}$ genes on plant development are helping to elucidate the general nature of phytohormone control of plant growth and development (Fladung, 1990; Schmulling et al., 1988; Spena et al., 1987; Sugaya et al., 1989; van Altvorst et al., 1992). Beyond these important basic studies, significant opportunities exist for using the rolC gene to manipulate horticultural crops genetically. Using tobacco, we have found that $\mathrm{rolC}$-induced alterations in growth were consistent, although not always of the same magnitude under different growing conditions of daylength and light intensity. RolC plants were dwarf in stature, but otherwise robust. Flowers were reduced in size by $\approx 15 \%$ but otherwise appeared normal. Seed capsule number did not differ between transgenic lines and controls (Tables 1 and 2). Due to reduced fertility of rolC transgenic lines, capsule number may not be a good indication of flower number, since some flowers may not set seed. Data taken from seedlings (Fig. 6) indicated that flower number on transgenic lines was higher than on untransformed controls. These seedlings originated from transgenic clone $\mathrm{E}$, which exhibited a more extreme expression of $\mathrm{rolC}$-related traits than most other clones. Increased flower number seemed to be related to extreme expression of rolCinduced growth alterations. The length of the flowering period did not differ between controls and transgenic lines. Interestingly, flowering was earlier (by up to 38 days) in transgenic clones.

The rolC gene used in our studies was controlled by its native promoter. It has been noted (Schmulling et al., 1988) that the growth-regulating functions of the $\mathrm{rolC}$ and $\mathrm{rolB}$ genes were more dramatic when controlled by the CaMV $35 \mathrm{~S}$ promoter. Therefore, promoter selection can be used to regulate the expression of the rolC gene in transgenic plants. Our work confirms earlier work (van Altvorst et al., 1992) that, under the control of a given promoter, the rolC gene produces a range of alterations in growth. Thus a great amount of phenotypic variation in gene expression can be obtained by using different promoters and furthered by selecting individual transgenic clones. We have shown that the gene is stably inherited and expressed in the progeny, in which again variation occurs and selection for gene expression can be made. Although further investigation is required, we expect that selecting for a particular level of expression can result in the establishment of lines homogeneous for that level of expression. Our results also indicate that, under different environmental conditions such as supplemental lighting vs. natural daylength and other conditions that caused differences in plant vigor between experiments, the rolC transgenic lines consistently exhibited the described growth alterations.

The rolC gene could significantly affect the development of improved ornamental crops. For example, inserting the rolC gene could result in producing earlier flowering, compact or miniature bedding plants, and reduced-stature foliage plants. It may also be possible to manipulate woody perennials with the rolC gene to produce dwarf or semidwarf cultivars. In the case of fruit or nut germplasm, the effects of the rolC gene on productivity and fruit and seed size need further investigation.

The rolC gene may also be useful in developing rootstocks. When used as rootstocks for potato or tomato, rolC transgenic plants do not affect scion growth because the rolC gene product is cytosol-specific and is not transported (Fladung, 1990; van Altvorst et al., 1992). However, differences in growth of rolC transgenic roots on woody perennials could be beneficial under particular environmental conditions (van der Salm et al., 1992). Altered growth of rolC transgenic lines may also indirectly influence scion growth. Thus, further investigations are necessary to determine the effects of rolC transgenic rootstocks on fruit, nut, and ornamental trees.

\section{Literature Cited}

An, G. 1987. Binary Ti vectors for plant transformation and promoter analysis. Method Enzymol. 153:292-305.

Doyle, J.J. and J.L. Doyle. 1990. Isolation of plant DNA from fresh tissue. BRL Focus 12:13-15.

Eissenstat, D.M. 1992. Costs and benefits of constructing roots of small diameter. J. Plant Nutr. 15:763-782.

Estruch, J.J., D. Chrique, K. Grossmann, J. Schell, and A. Spena. 1991a. The plant oncogene rolC is responsible for the release of cytokinins from glucosidase conjugates. EMBO J. 10:2889-2895.

Estruch, J.J., A. Parets-Soler, T. Schmulling, and A. Spena. 1991b. Cytosolic location in transgenic plants of the rolC peptide from Agrobacterium rhizogenes. Plant Mol. Biol. 17:547-550.

Fitch, M.M.M., R.M. Manshardt, D. Gonsalves, J.L. Slightom, and J.C. Sanford. 1992 Virus resistant papaya plants derived from tissues bombarded with the coat protein gene of papaya ringspot virus. BioTechnology 10:1466-1472.

Fladung, M. 1990. Transformation of diploid and tetraploid potato clones with the rolC gene of Agrobacterium rhizogenes and the characterization of transgenic plants. Plant Breeding 104:295-304.

Hamill, J.D., S. Rounsley, A. Spencer, G. Todd, and M.J.C. Rhodes. 1991. The use of polymerase chain reaction in plant transformation studies. Plant Cell Rpt. 10:221224

Hood, E.E., G.L. Helmer, R.T. Fraley, and M. Chilton. 1986. The hypervirulence of Agrobacterium tumefaciens A281 is encoded in a region of pTiBo542 outside of TDNA. J. Bacteriol. 168:1291-1301.

Jefferson, R.A. 1987. Assaying chimeric genes in plants: The GUS gene fusion system. Plant Mol. Biol. Rpt. 5:387-405.

Micke, A., B. Donini, and M. Maluszynski. 1987. Induced mutations for crop improvement-A review. Trop. Agr. (Trinidad) 64:259-278.

Murashige, T. and F. Skoog. 1962. A revised medium for rapid growth and bioassays with tobacco tissue cultures. Physiol. Plant. 15:473-497.

Oono, Y., T. Handa, J. Kanaya, and H. Uchimiya. 1987. The TL-DNA gene of Ri plasmids responsible for dwarfness of tobacco plants. Jpn. J. Genet. 62:501-505.

Rotino, G.L., D. Perrone, P. Ajmone-Marsan, and E. Lupotto. 1992. Transformation of Solanum integrifolium Poir via Agrobacterium tumefaciens: Plant regeneration and progeny analysis. Plant Cell Rpt. 11:11-15.

SAS Institute. 1979. SAS users guide. SAS Inst., Raleigh, N.C. p. 143-155.

Schmulling, T., J. Schell, and A. Spena. 1988. Single genes from Agrobacterium rhizogenes influence plant development. EMBO 7:2621-2629.

Slightom, J.L., M. Durand-Tardif, L. Jouanin, and D. Tepfer. 1986. Nucleotide sequence analysis of TL-DNA of Agrobacterium rhizogenes agropine type plasmid. J. Biol. Chem. 261:108-121.

Smigocki, A.C. and F.A. Hammerschlag,. 1991. Regeneration of plants from peach embryo cells infected with a shooty mutant strain of Agrobacterium. J. Amer. Soc. Hort. Sci. 116:1092-1097.

Southern, E. 1975. Detection of specific sequences among DNA fragments separated by gel electrophoresis. J. Mol. Biol. 98:503-517.

Spena, A., T. Schmulling, C. Kincz, and J.S. Schell. 1987. Independent and synergistic activity of rolA, $\mathrm{B}$ and $\mathrm{C}$ loci in stimulating abnormal growth in plants. EMBO 6:3891-3899.

Spena, A., R.B. Aalen, and S.C. Schulze. 1989. Cell autonomous behavior of the rolC gene of Agrobacterium rhizogenes during leaf development: A visual assay for transposon excision in transgenic plants. Plant Cell 1:1157-1164.

Sugaya, S., K. Hayakawa, T. Handa, and H. Uchimiya. 1989. Cell-specific expression of the rolC genes of the TL-DNA of Ri plasmids in transgenic tobacco plants. Plant Cell Physiol. 30:649-653.

Tepfer, D. 1984. Transformation of several species of higher plants by Agrobacterium rhizogenes: Sexual transmission of the transformed genotype and phenotype. Cell 37:959-967.

van Altvorst, A.C., R.J. Bino, A.J. van Dijk, A.M.J. Lamers, W.H. Lindhout, F. vanderMark, and J.J.M. Dons. 1992. Effects of the introduction of Agrobacterium rhizogenes rol genes on tomato plant and flower development. Plant Sci. 83:77-85. van der Salm, T.P.M., C.J.G. van der Toorn, Ch. H. Hanisch ten Cate, L.A.M. Dubois, D.P. de Vries, J.J.M. Dons. 1992. Introduction of rol genes in rootstocks of rose. Physiol. Plant. 85:A7 Abstr. 42.

Werner, D.J. and S. Chang. 1981. Stain testing viability in stored peach pollen. HortScience 16:522-523. 